\title{
Serious game for locomotor rehabilitation of hemiparetic stroke patients
}

Jogo sério para reabilitação locomotora de pacientes hemiparéticos por acidente vascular cerebral

Juego serio para rehabilitación locomotora de pacientes hemiparéticos por accidente cerebrovascular

Fernando Luís Fischer Eichinger $\mathbb{C l}^{[a, b]}$, Antonio Vinicius Soares $\mathbb{( b , c ]}$, Fabrício Noveletto $\mathbb{C}^{[a, d]}$, Yoshimasa Sagawa Júnior $\mathbb{[}[\mathrm{e}]$, Pedro Bertemes Filho $\mathbb{[}[\mathrm{d}]$, Susana Cristina Domenech $\mathbb{[}[\mathrm{f}] *$

[a] Faculdade Guilherme Guimbala, Joinville, SC, Brazil

[b] Universidade da Região de Joinville (Univille), Joinville, SC, Brazil

[c] Faculdade IELUSC, Joinville, SC, Brazil

[d] Universidade do Estado de Santa Catarina (Udesc), Joinville, SC, Brazil

[e] University of Franche-Comté, Besançon, France

[f] Universidade do Estado de Santa Catarina (Udesc), Florianópolis, SC, Brazil

\section{Abstract}

Introduction: Hemiparesis post-stroke usually results in locomotor limitations. As conventional rehabilitation is monotonous, the Serious Games (SG) represents an excellent treatment strategy, allowing to perform physical training in an interesting and enjoyable way. Objective: To evaluate the effects of an exercise program using the SG developed for hemiparetic stroke patients' locomotor rehabilitation. Method: Non-Randomized Controlled

* FLFE: MS, e-mail: fernando_lfe@hotmail.com AVS: PhD, e-mail: antonio.soares@ielusc.br FN: PhD, e-mail: bitbasico@gmail.com YSJ: PhD, e-mail: ysagawajunior@chu-besancon.fr PBF: PhD, e-mail: pedro.bertemes@udesc.br SCD: PhD, e-mail: susana.domenech@udesc.br 
Clinical Trial. Twenty-four hemiparetic stroke patients with subacute or chronic stroke (twelve men), mean age of $57.8 \pm 10.4$ years (injury time of $16.8 \pm 19.6$ months) participated in the study. The experimental group $(\mathrm{n}=16)$ participated in an exercise program with the SG for lower limb rehabilitation. The control group $(n=8)$ received conventional treatment (kinesiotherapy). The intervention consisted of sessions twice a week for ten weeks. The following parameters were assessed: muscle strength (dynamometry), spasticity (Modified Ashworth Scale), functional mobility (Timed Up and Go Test - TUGT), and the gait speed (GS). Results: Both groups showed improvements, but the experimental group was better in all the studied variables, the muscular strength of the lower limb paresis and of the quadriceps femoris $(p=0.002 ; d=0.7)$; and for the hamstrings ( $p<0.001 ; d=1.3$ ), TUGT ( $p<0.001 ; d=0.4)$, and GS ( $p=0.001 ; d=0.4)$. Conclusion: The exercise program with the SG was useful for the patients treated in this study. The results showed a superiority of the $S G$ regarding the conventional treatment in all the controlled variables. This was probably because of the greater repeatability of the exercises and the increased attention and motivation.

Keywords: Video Games. Exercise Therapy. Lower Extremity. Paresis. Stroke.

\section{Resumo}

Introdução: A hemiparesia pós-acidente vascular cerebral (AVC) habitualmente resulta em limitações locomotoras. Como a reabilitação convencional é monótona, os Jogos Sérios (JS) representam uma excelente estratégia de tratamento, permitindo realizar o treinamento físico de forma interessante e prazerosa. Objetivo: Avaliar os efeitos de um programa de exercícios utilizando um JS desenvolvido para reabilitação locomotora de pacientes hemiparéticos pós-AVC. Método: Ensaio Clínico Controlado Não-Randomizado. Participaram do estudo 24 hemiparéticos pós-AVC na fase subaguda ou crônica (12 homens), com idade média de $57.8 \pm 10.4$ anos (tempo de lesão $16.8 \pm 19.6$ meses). $O$ grupo experimental $(n=16)$ participou de um programa de exercícios com JS para reabilitação do membro inferior. O grupo controle $(n=8)$ recebeu tratamento convencional (cinesioterapia). A intervenção durou 10 semanas, com frequência de duas sessões semanais. Foram avaliados: força muscular (dinamometria), espasticidade (Escala de Ashworth Modificada), mobilidade funcional (Timed Up and Go Test-TUGT) e a velocidade da marcha. Resultados: Ambos os grupos apresentaram melhoras, sendo o grupo experimental superior em todas as variáveis estudadas, destaque para a força muscular do membro inferior parético, para o quadríceps femoral ( $p=0.002 ; d=0.7)$ e para os isquiotibiais ( $p<0.001 ; d=1.3)$, TUGT ( $p<0.001 ; d=0.4)$ e velocidade da marcha $(p=0.001 ; d=0.4)$. Conclusão: o programa de exercícios com o JS foi útil no tratamento dos pacientes envolvidos neste estudo. Os resultados apontaram uma superioridade do JS em comparação ao tratamento convencional em todas as variáveis controladas. Provavelmente isto ocorreu pela maior repetibilidade dos exercícios e aumento da atenção e motivação.

Palavras-chave: Jogos de Vídeo. Terapia por Exercício. Extremidade Inferior. Hemiparesia. Acidente Vascular Cerebral.

\section{Resumen}

Introducción: La hemiparesia post-accidente cerebrovascular (ACV) habitualmente resulta en limitaciones locomotoras. Como la rehabilitación convencional es monótona, los Juegos Serios (JS) representan una excelente estrategia de tratamiento, que le permite realizar el entrenamiento físico de forma interesante y placentera. Objetivo: Evaluar los efectos de un programa de ejercicios utilizando un JS desarrollado para rehabilitación locomotora de pacientes hemiparéticos post-ACV. Método: Ensayo Clínico Controlado no aleatorizado. En el estudio, participaron 24 pacientes hemiparéticos post-ACV en la fase subaguda o crónica (12 hombres), con un promedio de edad de $57,8 \pm 10,4$ años (tiempo de lesión 16,8 $\pm 19,6$ meses). El grupo experimental $(n=16)$ participó de un programa de ejercicios con JS para rehabilitación del miembro inferior. El grupo de control $(n=8)$ recibió tratamiento convencional (Kinesioterapia). Se realizaron dos sesiones semanales, durante diez semanas. Se evaluaron: fuerza muscular (dinamometría), espasticidad (Escala de Ashworth modificada) y movilidad funcional (Timed Up and Go Test - TUGT). Resultados: Ambos grupos presentaron mejoras, siendo que el grupo experimental fue superior en 
todas las variables estudiadas, destaque principalmente para la fuerza muscular del miembro inferior parético, para el cuádriceps femoral ( $p=0.002 ; d=0.7)$ y para los isquiotibiales ( $p<0.001 ; d=1.3)$, TUGT $(p<0.001 ; d=0.4)$ y velocidad de marcha ( $p=0.001 ; d=0.4)$. Conclusión: El programa de ejercicios con el JS fue útil en el tratamiento de los pacientes involucrados en este estudio. Los resultados mostraron una superioridad del JS en comparación con el tratamiento convencional en todas las variables controladas. Probablemente esto ocurrió por la mayor repetibilidad de los ejercicios y aumento de la atención y motivación.

Palabras claves: Juegos de Vídeo. Terapia por Ejercicio. Miembro Inferior. Hemiparesia. Accidente Cerebrovascular.

\section{Introduction}

Stroke is a serious worldwide public health problem, as it has high rates of morbidity and mortality $[1,2]$. This pathological condition can cause several clinical changes, such as motor, sensory, perceptive, cognitive, and language impairment [3]. Individuals who have had a stroke can have their quality of life impaired, even without significant limitations in functional capacity [4].

Motor dysfunction is one of the most encountered problems and is the most obvious consequence after a stroke [5]. The main motor deficit is hemiparesis, a classic clinical picture of this disease [3]. Studies point to muscle weakness as the primary impairment, and it is the main limiting factor of motor and functional performance in these patients $[5,6]$.

To regain locomotor capacity is one of the main goals in these patients' rehabilitation. In this sense, conventional rehabilitation techniques produce positive results over time [7], especially muscle strengthening programs that reduce strength deficits $[8,9]$. However, such strategies have as a limiting factor, monotony and boredom in exercise [10], which often generate motivational problems and reduce adherence to treatment programs [11]. In this sense, the digital games are one of the rehabilitation strategies that must be highlighted and have been recommended in these patients' rehabilitation [12]. However, in most cases commercial games [13] that are not designed for rehabilitation, but rather for the entertainment of healthy people, are used in the treatment, which limits their application and therapeutic safety. An alternative to reduce these limitations is to use the so-called Serious Games (SG) [14].

There is already evidence on the beneficial effects of applying SG-based rehabilitation exercise programs on hemiparetic stroke patients, but these are directed to the upper limb. There is still a gap regarding the evidence on the effects of this type of intervention for the locomotion recovery. In addition, there is also a lack of studies comparing the effects of SG-based programs with conventional rehabilitation modalities [15].

Therefore, this study aims to evaluate the effects of an exercise program using a SG developed for locomotor rehabilitation of hemiparetic patients by stroke.

\section{Methods}

This is a non-randomized controlled clinical trial involving 24 hemiparetic stroke patients. The study was conducted at the Center for Neurorehabilitation Research (NUPEN), attached to the Neurological Rehabilitation Clinic of Faculdade Guilherme Guimbala, Joinville, Santa Catarina, Brazil.

The inclusion criteria were clinically stable hemiparetic stroke patients in the subacute or chronic phase of the disease, who were capable of walking independently. The exclusion criteria were: hemiparesis because of other pathologies, severe visual and/or hearing impairment, non-cooperative patients and/or with severe cognitive impairment, as well as patients who were performing any other type of upper body and/or lower limb rehabilitation in the last three months.

This study was approved by the UDESC Research Ethics Committee (CAAE 56995816.6.0000.0118), and the Brazilian Registry of Clinical Trials (RBR-2MF595).

The used measurement instruments were chosen according to the domains of the International Classification of Functioning, Disability and Health (ICF), created by the World Health Organization in 2004. 
Regarding the Function/Body Structure (ICF) domain, many instruments were used. The anthropometric digital scale and stadiometer was used to measure body mass and height, respectively (which provided the patient's BMI - Body mass index). The Fugl-Meyer Assessment Scale (FMAS) [16] measured the level of the patients' motor impairment in the preand post-intervention period (note that only motor assessment for the lower limb section was used, which includes reflex activity analysis, synergistic muscle action in flexion and extension, and movements with and without synergy), and the patients were classified according to the degree of motor impairment as Severe (0-7), Striking ( $>7$ to 14), Moderate ( $>14$ to 21), and Mild ( $>21$ to 28). The Modified Ashworth Scale (MAS) assessed spasticity, but only the quadriceps femoris (QF) was evaluated and the classification ranged from 0 to 5 , where 0 is considered normal, and 5 when there was a significant increase in tone that made movement impossible, keeping the rigid body segment in flexion or extension (the 0 to 5 scale was used to ease statistical analysis). The Mini Mental State Examination (MMSE) assessed the patients' cognitive level (this instrument was used only for screening them, adopting the cut-off points related to education [17]). The SG mim-Pong assessed and trained the patients' muscular strength (MS). This game operates through a compression load cell-based system (589 N capacity). Two lower limb muscle groups were evaluated: QF and hamstrings (HS).

The biomedical system consists of a specific hardware and software, and the hardware uses dynamometry to obtain the strength signal of the mentioned muscles.

For the MS assessment, the load cell was coupled to a device that allows the adjustment and positioning of the region to be stimulated, also acting as a dynamometer in the strength measurement of any muscle group [18]. The software enables configuration of hardware-related parameters, calibration for acquisition initiation, real-time visualization of the captured signal, and recording of data to file. This SG has simple visual aspects, so that the patient remains focused only on hitting the ball. The rackets move simultaneously on the vertical walls as a function of the signal from the used load cell, which can be individually calibrated by the measurement of maximal voluntary isometric contraction (MVIC) of each muscle group in each session. The game also makes it possible to adjust the size of the racket, the size and speed of the ball, and the duration of the game. The horizontal walls hit the ball. The score serves to inform the patient's performance during the training, and considers aspects related to the gameplay. Figure 1 shows the main used SG screen.

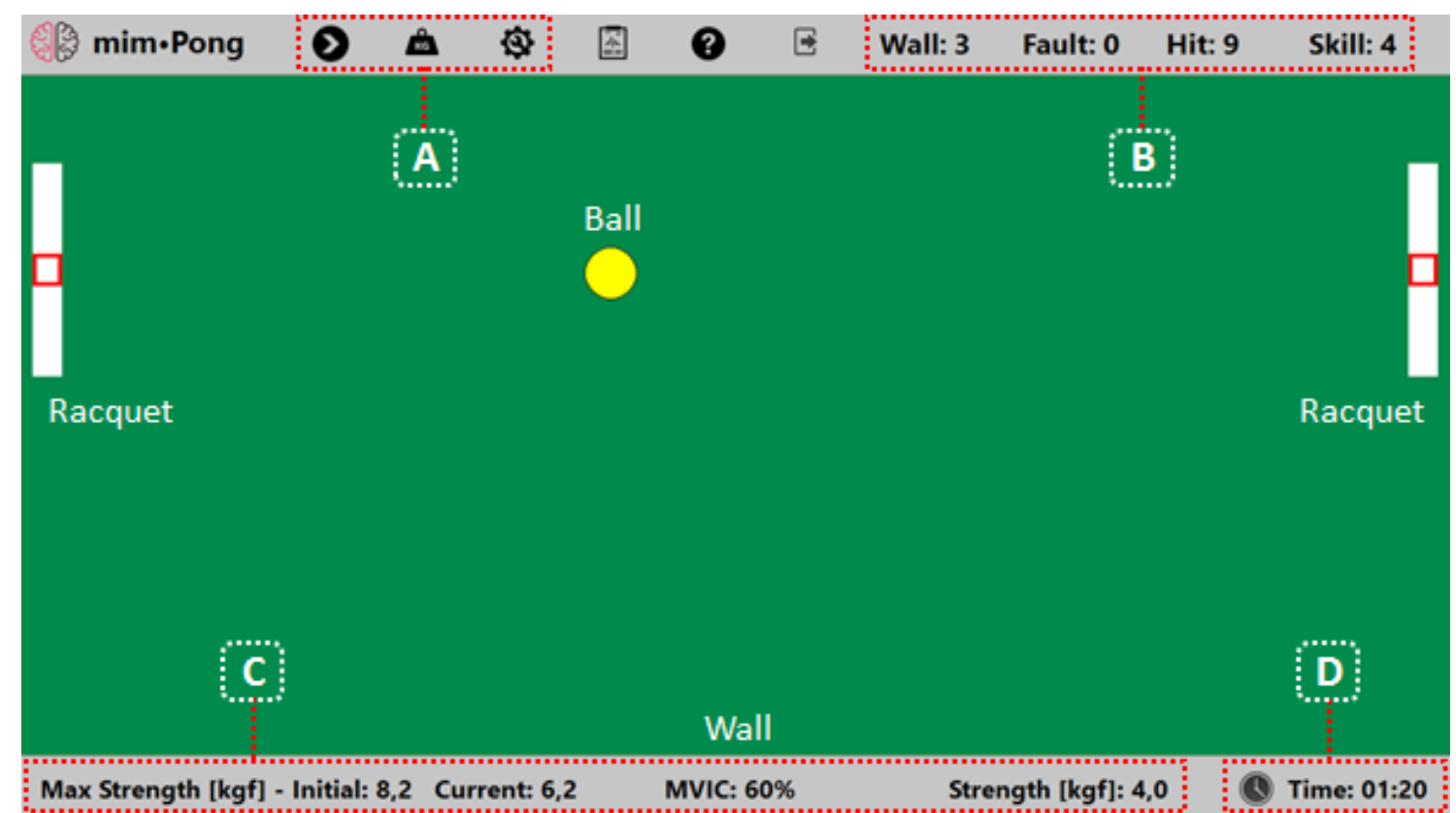

Note: A: Game control and settings; B: Game score components; C: Muscle strength data; D: Remaining training time. Source: The authors, 2019

Figure 1-Main screen of the SG mim-Pong. 
For the Activities domain (ICF), the following instruments were used: Timed Up and Go Test (TUGT), to assess functional mobility by measuring the time taken to perform the proposed task [19]; and the Gait Speed Test (GST) to evaluate the walking speed, which is the most objective and simple measure of locomotor performance [6]. The test should be performed as soon as possible and a 10-meter timing course was selected. At the beginning and end of the course, 3 meters were added to eliminate the acceleration and deceleration effects in the test.

The study participants were divided into two nonrandomized groups: the Experimental Group (EG = 16) and the Control Group ( $\mathrm{CG}=8)$. Three assessments were performed before the rehabilitation program (pre-intervention) and another three at the end of the program (post-intervention). All assessments were performed by the same examiners on different days, with a minimum interval of 24 hours each.

To carry out the assessment and training with the SG mim-Pong, it was adapted with a load cell coupled to a chair, which allowed to bilaterally assess the strength of the muscle groups mentioned above. Patient and equipment positioning were different for each muscle group. For the QF, the patient was seated in the chair, with the upper body resting on the back, with legs hanging, hip at $110^{\circ}$ of flexion compared to the upper body, and knees flexed at $90^{\circ}$ [20]. For this muscle group, the equipment (load cell sensor) was positioned at the level of the distal third of the leg (just above the malleolar region) on the anterior face. For the HS, the patient was seated in the chair, with the upper body resting on the back, hip at $110^{\circ}$ of flexion compared to the upper body, and knees flexed at $60^{\circ}$ [21]. For this muscle group, the equipment was also positioned at the level of the distal third of the leg, but on the posterior face. Figure 2 shows the biomedical system developed and the patient's interaction with it.

For the assessment, three measurements were taken bilaterally of each muscle group in the MVIC over a period of 5 seconds, with an interval of 1 minute between each measurement [22]. The arithmetic mean resulting from the three assessments was recorded. The patient was instructed to perform as much force as possible when a green signal was projected on the screen, which indicated the start of the test, and this force should be maintained until the green signal disappeared, indicating the end of the test. This information served to calibrate the system at each treatment session.

After the assessment phase, patients from both groups underwent the same treatment period, which consisted of 10 consecutive weeks, with two weekly sessions, totaling 20 sessions.

The EG consisted of 16 patients who received an exercise-based paretic lower limb rehabilitation program using the SG mim-Pong. This exercise program was divided into two phases of 10 sessions: Phase 1 (using 60\% of the MVIC) and Phase 2 (using $80 \%$ of the MVIC) [9]. All patients used the same game configuration (racket size, ball size, and ball speed). In each session, the first passive mobilization of the paretic hemibody was performed for a period of 10 minutes, after the training began. The SG calibration was always performed by measuring the MVIC and, after obtaining this data, the exercise with the patient started. There were three game series, lasting 2 minutes each and with 1-minute interval between them. It always started with the strengthening of the QF, followed by the exercises for the HS.
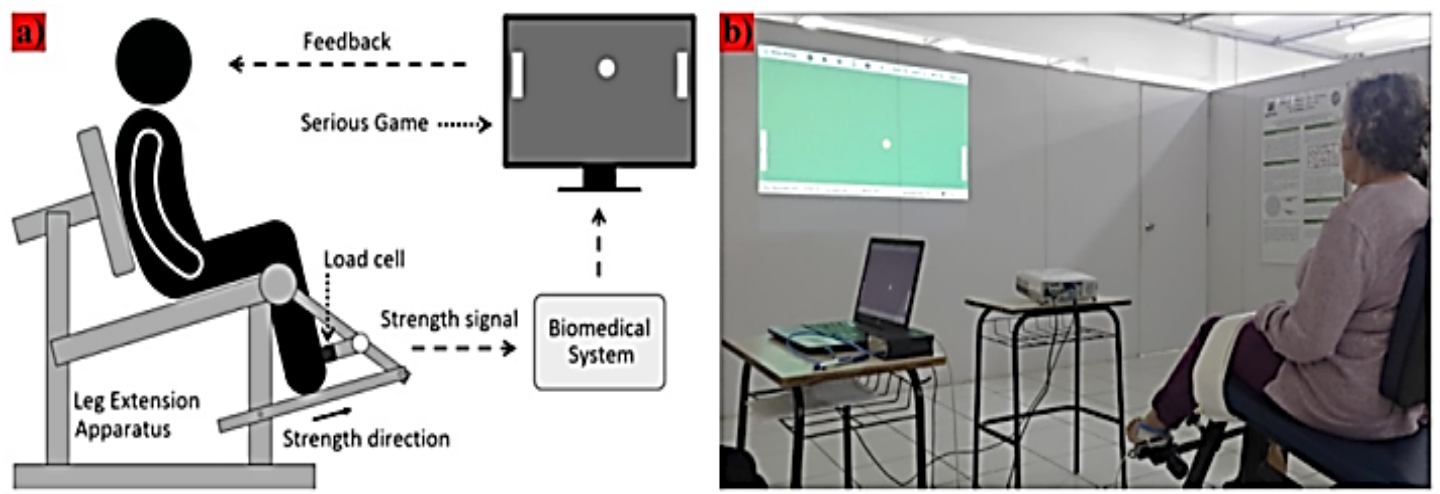

Note: a: Diagram of patient's position and system components; b: Patient interacting with the SG min-Pong. Source: The authors, 2019.

Figure 2 - Patient's positioning during the session with the SG min-Pong. 
But the CG was composed of eight patients, who received a rehabilitation program based on conventional kinesiotherapy (passive mobilization, stretching, and active-assisted exercise). The sessions with this group lasted 30 minutes.

\section{Data analysis}

The data were analyzed using the SPSS - IBM software, version 20.0. Descriptive analysis used mean and standard deviation (for parametric data), as well as median, interquartile range and frequency distribution (for nonparametric data). The $2 \times 2$ ANOVA was used to verify the effect of the group (experimental and control) and the effect of the condition (pre- and post-intervention) on the studied parameters. Data normality was verified by the Shapiro-Wilk test, the homogeneity of variances by the Levene test, and sphericity by the Mauchly test.

The variables that did not meet the assumptions for the 2x2 ANOVA, underwent two-group comparison tests, the independent t-test or the Mann-Whitney U-test, when comparing GE and GC, and the paired t-test or the Wilcoxon for sum of posts when comparing pre- and post-intervention conditions. The effect size (ES) was calculated to complete the analysis of clinical effects of the interventions on each variable, considering $0.8,0.5$, and 0.2 (large, moderate, and small, respectively.) For nonparametric data 0.5, 0.2, and 0.1 were considered (large, moderate, and small, respectively) [23]. A significance level of $95 \%$ was used for all tests.

\section{Results}

Twenty-four hemiparetic stroke patients (12 men), with a mean age of $57.8 \pm 10.4$ years, and with a mean time since stroke of $16.8 \pm 19.6$ months participated in the study. Table 1 shows the EG and CG participants' sociodemographic, clinical, and anthropometric profile.

There was no difference between the groups in any of the variables showed in w. There was a predominance of ischemic stroke in both groups ( $\mathrm{EG}=80.0 \%$ and $\mathrm{CG}=62.5 \%$ ), and there was a prevalence of left hemiparesis.

Table 1 - The participants' socio-demographic, clinical, and anthropometric profile

\begin{tabular}{|c|c|c|c|c|}
\hline \multirow{2}{*}{ Features } & \multicolumn{2}{|c|}{ GE $(n=16)$} & \multicolumn{2}{|c|}{$\mathrm{GC}(n=8)$} \\
\hline & $\dot{x} \pm s$ & $f(\%)$ & $\dot{x} \pm s$ & $f(\%)$ \\
\hline \multicolumn{5}{|l|}{ Sex } \\
\hline Female & --- & $8(50.0)$ & $--\cdot$ & $4(50.0)$ \\
\hline Male & $--\cdot$ & $8(50.0)$ & ---- & $4(50.0)$ \\
\hline Age (complete age) & $56.8 \pm 10.8$ & --- & $59.8 \pm 9.8$ & --- \\
\hline \multicolumn{5}{|l|}{ Self-reported ethnicity } \\
\hline White & --- & 14 (87.5) & --- & $7(87.5)$ \\
\hline Black & --- & $2(12.5)$ & --- & $1(12.5)$ \\
\hline $\mathrm{BMI}\left(\mathrm{kg} / \mathrm{m}^{2}\right)$ & $29.1 \pm 7.8$ & --- & $28.3 \pm 5.8$ & --- \\
\hline \multicolumn{5}{|l|}{ Self-reported laterality } \\
\hline Right-handed & $--\cdot$ & $16(100)$ & --- & $5(62.5)$ \\
\hline Left-handed & $--\cdot$ & $0(0)$ & --- & 1 (12.5) \\
\hline Ambidextrous & $--\cdot$ & $0(0)$ & --- & $2(25.0)$ \\
\hline \multicolumn{5}{|l|}{ Hemiparesis } \\
\hline Left & $--\cdot$ & $9(56.3)$ & $--\cdot$ & $4(50.0)$ \\
\hline Right & --- & 7 (43.7) & --- & $4(50.0)$ \\
\hline Time suffering from stroke (months) & $19.3 \pm 23.1$ & & $13.8 \pm 12.3$ & \\
\hline \multicolumn{5}{|l|}{ Stroke stage } \\
\hline Sub-acute &.-- & $5(31.3)$ &.-- & $3(37.5)$ \\
\hline Chronic & --- & $11(68.7)$ & --- & $5(62.5)$ \\
\hline \multicolumn{5}{|l|}{ Stroke types } \\
\hline Ischemic & --- & $13(81.3)$ & --- & $5(62.5)$ \\
\hline Hemorrhagic & --- & $3(18.7)$ & --- & $3(37.5)$ \\
\hline
\end{tabular}

Note: BMl: body mass index; $\mathrm{n}$ : total sample; f: absolute frequency. 
All variables have already been classified in the methodology according to the ICF. Data on FMAS, MAS, and muscle strength measurements belong to the domain: Function / Structure Body, the TUGT; the GST, of the domain: Activities. Table 2 shows the results of the groups' effect analysis and the condition on the studied variables that did not present normal distribution.

Regarding the comparison between groups, there is a difference between pre- and postintervention, which is independent between EG and CG. In the pre-intervention condition, no statistically significant differences were observed between the groups in the following variables: TUGT ( $U=64.00 ; \mathrm{p}=0.5)$; MAS $(\mathrm{U}=60.00$; $\mathrm{p}=0.417) ;$ FMAS $(\mathrm{t}=-0.543 ; \mathrm{p}=0.296) ;$ and MSQF-NP ( $\mathrm{t}=0.126 ; \mathrm{p}=0.451)$. Similarly, in the post-intervention condition, no statistically significant differences were observed between EG and CG in the TUGT (U = 57.00; $p=0.349)$ and MAS $(U=61.00 ; p=0.440)$ variables; FMAS $(U=61.5$; $\mathrm{p}=0.440)$; and MSQF-NP $(\mathrm{U}=52.00 ; \mathrm{p}=0.245)$.

Table 2 - Groups' effect (experimental and control) and condition (pre- and post-intervention) on the study variables

\begin{tabular}{|c|c|c|c|c|}
\hline \multirow[b]{2}{*}{ Group } & \multirow[b]{2}{*}{ Variables } & \multicolumn{2}{|c|}{ Condition } & \multirow[b]{2}{*}{$d$} \\
\hline & & $\begin{array}{l}\text { Pre-intervention } \\
\text { Md (dq) ou } x^{\prime} \pm s d p\end{array}$ & $\begin{array}{l}\text { Post-Intervention } \\
\text { Md (dq) ou } \dot{x} \pm s d p\end{array}$ & \\
\hline \multirow{4}{*}{ Experimental $(n=16)$} & TUGT (s) & $22.50(21.39)^{y}$ & $18.36(16.51)^{y}$ & 0.4 \\
\hline & FMAS & $21.13 \pm 4.76^{y}$ & $24.50(3.75)^{y}$ & 0.6 \\
\hline & MAS & $1.00(2.00)^{y}$ & $0.00(0.75)^{y}$ & 0.5 \\
\hline & MSQF-NP (kgf) & $24.29 \pm 7.30 y$ & $25.30(11.35) y$ & 0.3 \\
\hline \multirow{4}{*}{ Control $(n=8)$} & TUGT (s) & $33.28 \pm 28.40$ & $28.93 \pm 21.99$ & 0.2 \\
\hline & FMAS & $22.37 \pm 6.34 y$ & $23.88 \pm 4.64 y$ & 0.5 \\
\hline & MAS & $0.50(4.00) y$ & $0.00(1.50) y$ & 0.5 \\
\hline & MSQF-NP (kgf) & $23.86 \pm 8.84$ & $24.15 \pm 9.95$ & 0.0 \\
\hline
\end{tabular}

Note: TUGT: Timed Up and Go Test; FMAS: Fugl-Meyer assessment scale; MAS: modified Ashworth scale; MSQF-NP: quadriceps femoris muscle strength in non-paretic limb; Md: median; dq: interquartile range; : average; SD: standard deviation; d: effect size; ' $x$ 'superscript: statistically significant difference between experimental and control groups, obtained by the t-test for independent data (parametric data) or by the MannWhitney U test (non-parametric data) ( $p<0.05$, unilateral). Superscript ' $y$ ': statistically significant difference between pre- and post-intervention conditions, obtained by the paired t-test (parametric data) or the Wilcoxon rank-sum test (non-parametric data) ( $p<0.05$, one-tailed test).

Comparing the conditions, in the EG, statistically significant differences were observed between the preand post-intervention condition in the variables TUGT $(\mathrm{z}=-3.516 ; \mathrm{p}<0.001)$, FMAS $(\mathrm{z}=-3.417 ; \mathrm{p}<0.001)$, MAS ( $\mathrm{z}=-2.739 ; \mathrm{p}=0.003)$, and MSQF-NP $(\mathrm{z}=-1.681$; $\mathrm{p}=0.046)$. In the CG, statistically significant differences were observed between the pre- and post-intervention condition in the FMAS $(\mathrm{t}=-1.121 ; \mathrm{p}=0.036)$ and MAS variables $(\mathrm{z}=-1,841 ; \mathrm{p}=0.033)$. However, no significant difference was found in the TUGT $(\mathrm{t}=1,264 ; \mathrm{p}=0.124)$ and MSQF-NP variables $(\mathrm{t}=-0,316 ; \mathrm{p}=0.380)$.

Table 3 shows the results of the groups' effect analysis and the condition on the studied variables that presented normal distribution.

Considering the GS variable, the main effect of the condition (pre- and post-intervention) was significant $(\mathrm{F}=10,592 ; \mathrm{p}=0.004 ;$ observed power $=0.875)$. The groups' main effect (experimental or control) had no significant effect $(F=0.092 ; p=0.764$; observed power $=0.06$ ), as did the interaction of the factors group * condition $(\mathrm{F}=3.317 ; \mathrm{p}=0.082$; observed $=0.414$ ).

When analyzing the MSQF variable, the main effect of the condition (pre- and post-intervention) was significant $(F=8,190 ; p=0.009$; observed power $=0.781$ ). The groups' main effect (experimental or control) had no significant effect $(\mathrm{F}=0.474$; $\mathrm{p}=0.500$; observed power $=0.101)$, similar to the interaction of the factors group * condition $(\mathrm{F}=5.035$; $\mathrm{p}=0.050$; observed $=0.574$ ).

Considering the MSHS variable, the main effect of the condition (pre- and post-intervention) was significant $(F=23,706 ; p<0.001$; observed power $=0.996$ ). The groups' main effect (experimental or control) had no significant effect $(\mathrm{F}=0.012$; $\mathrm{p}=0.912$; observed power $=0.051$ ), similar to the interaction of the factors group ${ }^{*}$ condition $(\mathrm{F}=10.995 ; \mathrm{p}<0.05 ;$ observed $=0.886)$. 
Table 3 - Groups' effect (experimental and control) and condition (pre- and post-intervention) on study variables

\begin{tabular}{|c|c|c|c|c|}
\hline \multirow{2}{*}{ Group } & \multirow{2}{*}{ Variables } & \multicolumn{2}{|c|}{ Condition } & \multirow{2}{*}{$d$} \\
\hline & & Pre-intervention ${ }^{\prime} \pm s d p$ & Post-Intervention $\dot{x} \pm s d p$ & \\
\hline \multirow{4}{*}{ Experimental $(n=16)$} & GS $(\mathrm{m} / \mathrm{s})$ & $0.55 \pm 0.31^{y}$ & $0.70 \pm 0.42^{y}$ & 0.4 \\
\hline & MSQF (kgf) & $14.80 \pm 6.63^{y}$ & $21.20 \pm 11.58 y$ & 0.7 \\
\hline & MSHS (kgf) & $5.40 \pm 2.96^{y}$ & $10.21 \pm 4.32^{y}$ & 1.3 \\
\hline & MSHS-NP (kgf) & $11.74 \pm 4.16^{y}$ & $15.24 \pm 5.24^{y}$ & 0.7 \\
\hline \multirow{4}{*}{ Control $(n=8)$} & GS $(\mathbf{m} / \mathbf{s})$ & $0.67 \pm 0.53^{y}$ & $0.70 \pm 0.54^{y}$ & 0.1 \\
\hline & MSQF (kgf) & $14.66 \pm 11.92^{y}$ & $15.44 \pm 11.99 y$ & 0.1 \\
\hline & MSHS (kgf) & $7.14 \pm 6.30^{y}$ & $8.05 \pm 6.03^{y}$ & 0.2 \\
\hline & MSHS-NP (kgf) & $12.78 \pm 6.99^{y}$ & $13.14 \pm 4.43^{y}$ & 0.1 \\
\hline
\end{tabular}

Note: GS: gait speed; MSQF: quadriceps femoris muscle strength; MSHS: hamstring muscle strength; MSHS-NP: hamstring muscle strength in the nonparetic limb; : average; SD: standard deviation; $d$ : effect size; ' $x$ 'envelope: statistically significant difference between experimental and control groups; ' $y$ ' superscript: statistically significant difference between pre- and post-intervention conditions, obtained by the $2 \times 2$ Anova test $(p<0.05$, unilateral).

Finally, when considering the MSHS-NP variable, the main effect of the condition (pre- and postintervention) was significant ( $\mathrm{F}=8,694 ; \mathrm{p}=0.007$; observed power $=0.804$ ). The groups' main effect (experimental or control) did not present a significant effect $(\mathrm{F}=0.064 ; \mathrm{p}=0.802$, observed power $=0.057$ ), as well as the interaction of the factors group * condition $(F=5.734 ; p<0.05$; observed $=0.629)$.

\section{Discussion}

The conventional rehabilitation methods produce positive long-term results [9], but are generally characterized by boredom and boring repeatability [10], which causes patient motivational and adherence problems [11], making it difficult to obtain positive results, or even resulting in treatment abandonment in some cases [24]. The development of the SG for rehabilitation has increased in recent years, precisely because it allows the patient to perform specific training without losing the motivational focus [25]. In this study, significant differences were found between pre- and post-intervention in both groups (experimental and control). However, patients who received the SG mim-Pong exercise program had significant improvements in all variables analyzed in the EG, especially in the QF and the HS muscle strength on the paretic side, which showed high ES.

In stroke patients, muscle weakness is the primary impairment [5], which commonly affects the lower extremity [26], especially the QF and the HS $[6,27]$, hindering significantly the individual's independence to perform daily living activities [28].

Regarding the effects of interventions on this variable in the EG, significant gains were obtained with high ES for QF and HS on the paretic side ( $p=0.003 d=0.7 / p<0.001 d=1.3$ ), besides HS on the non-paretic side $(p=0.001 \mathrm{~d}=0.7)$. One hypothesis for the assessed change in the non-paretic limb is the increase in activities routinely performed by the patients from the moment they present an increase in muscular strength in the paretic limb, for example. This may increase their frequency and ambulation distance, as well as in performing basic activities, such as sitting and rising, or climbing and descending stairs [28]. In a systematic review of twelve studies that emphasized strength training in hemiparetic patients, the authors noted that although this treatment strategy results in functional benefits, especially in the patients' lower limb, the main limitation of these studies was the lack of procedures standardization[8].

Regarding the functional mobility variable, a longitudinal study [19] assessed the performance of 91 patients on the TUGT in the first week, the third month, the sixth month, and the twelfth month after the stroke. Significant improvement in test performance was observed only in the first three months of the disease (acute phase). These findings differ from the literature, since most patients were chronic, and yet showed significant improvement verified by the same measuring instrument, Showing 
it is superior to the conventional treatment (GE: $\mathrm{p}<0.001 ; d=0.3$ vs GC: $\mathrm{p}=0.247 ; d=0.2$ ).

In the walking speed variable, even performance in clinical trials is strongly related to functional capacity and is therefore considered as the "sixth vital sign" [29]. This study pointed to significant improvements with moderate ES in this variable after intervention with the GE-based SG exercise program ( $p=0.003 \mathrm{~d}=0.4$ ). In the $\mathrm{CG}$, the improvements were not significant, and the ES was small $(\mathrm{p}=0.204 \mathrm{~d}=0.1)$. The patients in question generally presented a moderate to severe impairment in walking speed (EG: $0.55 \pm 0.31 \mathrm{~m} / \mathrm{s}$ and CG: $0.67 \pm 0.53 \mathrm{~m} / \mathrm{s})[7,29,30]$. Some studies with good level of evidence and degree of recommendation using virtual reality technologies to improve motor functions in hemiparetic stroke patients point to gait-related improvements [31]. In general, the results of these studies corroborate those obtained in this study, indicating improvements in the various walking parameters, including speed.

Regarding motor impairment and spasticity, significant and moderate ES improvements were also observed in the EG (FMAS $\mathrm{p}=0.001 \mathrm{~d}=0.6$; MAS $p=0.010 \mathrm{~d}=0.5$ ). In the CG, no significant improvements were obtained in these variables, however, the ES was moderate, perhaps because of the reduced participants' number in this group [32].

Most participants from both groups were in the chronic phase of the disease (EG: $19.3 \pm 23.1$ months and CG: $13.8 \pm 12.3$ months), a period characterized by greater difficulty in obtaining results when compared to the subacute phase [33]. The participants' characteristics make the results valuable and promising as they indicate that the intervention with the SG mim-Pong may represent a useful and viable new therapeutic resource, even at this stage of hemiparesis recovery. Such positive effect has already been observed as a result of chronic phase hemiparetic balance training using a specific SG called MyBalance [34].

\section{Conclusions}

The analysis of the therapeutic effects of the different treatment modalities used in this study clearly indicated significant increases in all variables studied in the EG, which were higher than those obtained in the CG. These findings indicate that the SG may be potentially beneficial for the rehabilitation of hemiparetic stroke patients, even in the chronic phase.

It is likely that these improvements may have resulted in gains in other daily activities involving these muscle groups, such as climbing and descending stairs, sitting and rising, among others. These changes are fundamental because they relate to the patients' functional independence, and possibly to the improvement of quality of life.

The limitations of the study refer to the small patients' number and the nonrandom characteristics of the groups. Future studies may address these issues and further detail the therapeutic potential that this resource represents for this population.

\section{Acknowledgment}

The authors would like to thank the institutional support of the Universidade da Região de Joinville (UNIVILLE), Universidade do Estado de Santa Catarina (UDESC), Faculdade Guilherme Guimbala, and Coordenação de Aperfeiçoamento de Pessoal de Nível Superior (CAPES).

\section{References}

1. Benjamin EJ, Blaha MJ, Chiuve SE, Cushman M, Das SR, Deo R, et al. Heart disease and stroke statistics-2017 Update: a report from the American Heart Association. Circulation. 2017;135(10):146-603.

2. Rist PM, Buring JE, Kase CS, Kurth T. Healthy lifestyle and functional outcomes from stroke in women. Am J Med. 2016;129(7):715-24.

3. Gibson CL, Attwood L. The impact of gender on stroke pathology and treatment. Neurosci Biobehav Rev. 2016;67:119-24.

4. Marinho C, Monteiro M, Santos L, Oliveira-Filho J, Pinto EB. Gait performance and quality of life in stroke survivors: a cross-sectional study. Rev Pesq Fisio. 2018;8(1):79-87.

5. Dorsch S, Ada L, Canning CG. Lower limb strength is significantly impaired in all muscle groups in ambulatory people with chronic stroke: a cross-sectional study. Arch Phys Med Rehabil. 2016;97(4):522-7. 
6. Roelker SA, Bowden MG, Kautz SA, Neptune RR. Paretic propulsion as a measure of walking performance and functional motor recovery post-stroke: a review. Gait Posture. 2019;68:6-14.

7. Winstein CJ,Stein J, Arena R, Bates B, Cherney LR, Cramer SC, et al. Guidelines for adult stroke rehabilitation and recovery. Stroke. 2016;47(6):98-169.

8. Barbosa DD, Trojahn MR, Porto DVG, Hentschke GS, Hentschke VS. Strength training protocols in hemiparetic individuals post stroke: a systematic review. Fisioter Mov. 2018;31:1-11.

9. Billinger SA, Arena R, Bernhardt J, Eng JJ, Franklin $\mathrm{BA}$, Johnson CM, et al. physical activity and exercise recommendations for stroke survivors. Stroke. 2014;4(8):2532-53.

10. Burdea GC. Virtual rehabilitation: benefits and challenges. |Methods Inf Med. 2003;42(5):519-23.

11. Burke JW, McNeill MDJ, Charles DK, Morrow PJ, Crosbie JH, McDonough SM. Optimising engagement for stroke rehabilitation using serious games. Visual Comput. 2009;25(12):1085-99.

12. Lohse KR, Courtney GE, Hilderman KL, Cheung ST, Van Der Loos HFM. Virtual reality therapy for adults post-stroke: a systematic review and meta-analysis exploring virtual environments and commercial games in therapy. PLoS One. 2014;9(3):1-13.

13. Deutsch JE, Brettler A, Smith C, Welsh J, John R, Guarrera-Bowlby P, Kafri M. Nintendo Wii Sports and Wii Fit game analysis, validation, and application to stroke rehabilitation. Top Stroke Rehabil. 2011;18(6):701-19.

14. Alvarez J, Djaouti D. An introduction to serious game definitions and concepts. Proceedings of the Serious Games \& Simulation Workshop; 2011; Paris.

15. Laver KE, George S, Thomas S, Deutsch JE, Crotty M. Virtual reality for stroke rehabilitation. Cochrane Database Syst Rev. 2011;(9):1-72.

16. Fugl-Meyer AR. Post-stroke hemiplegia: assessment of physical properties. Scand J Rehabil Med. 1980;7:85-93.
17. Bertolucci PHF, Brucki SMD, Campacci SR, Juliano Y. O mini-exame do estado mental em uma população geral: impacto da escolaridade. Arq Neuropsiquiatr. 1994;52(1):1-7.

18. Noveletto F, Watanabe ATY, Bertemes Filho P, Soares AV, Marcelino E. Dynamometry as a coadjuvant analysis for the characterization of frailty syndrome in the elderly. VI Congreso Latinoamericano de Ingeniería Biomédica; 2014 Oct 29-31; Paraná, Argentina. Basel: IFMBE Proceeding; 2014.

19. Persson CU, Danielsson A, Sunnerhagen KS, Grimby-Ekman A, Hansson PO. Timed Up \& Go as a measure for longitudinal change in mobility after stroke - Postural stroke study in Gothenburg (POSTGOT). J Neuroeng Rehabil. 2014;11:83.

20. Cooper A, Alghamdi GA, Alghamdi MA, Altowaijri A, Richardson $\mathrm{R}$. The relationship of lower limb muscle strength and knee joint hyperextension during the stance phase of gait in hemiparetic stroke patients. Physiother Res Int. 2011;17(3):150-6.

21. Correa CS, Silva BGC, Alberton CL, Wilhelm EN, Moraes AC, Lima CS, et al. Análise da força isométrica máxima e do sinal de EMG em exercícios para os membros inferiores. Rev Bras Cineantropom Desempenho Hum. 2011;13(6):429-5.

22. Souza LA, Martins JC, Teixeira-Salmela LF, Lara EM, Moura JB, Aguiar LT, Morais Faria CD. Validity and reliability of the modified sphygmomanometer test to assess strength of the lower limbs and trunk muscles after stroke. J Rehabil Med. 2014;46(7):620-8.

23. Cohen J. Statistical Power Analysis for the Behavioral Sciences. 2nd ed. Hillsdale: Erlbaum; 1988.

24. McGrane N, Galvin R, Cusack T, Stokes E. Addition of motivational interventions to exercise and traditional Physiotherapy: a review and metaanalysis. Physiotherapy. 2015;101(1):1-12.

25. Brückheimer AD, Hounsell MS, Soares AV. Dance2Rehab3D: a 3D virtual rehabilitation game. 14th Symposium on Virtual and Augmented Reality; 2012 May 28-31; Niterói, Brazil. Piscataway: IEEE; 2012. 
26. Aaron SE, Hunnicutt JL, Embry AE, Bowden MG, Gregory CM. Power training in chronic stroke individuals: differences between responders and nonresponders. Top Stroke Rehabil. 2017;24(7):496-502.

27. Hsiao Ching Y, Jer Junn L, Ting T, Guan Shuo P, Wen Shiang C, Chiang Chang H, et al. Reliability of lower extremity muscle strength measurements with handheld dynamometry in stroke patients during the acute phase a pilot reliability study. J Phys Ther Sci. 2017;29(2):317-22.

28. Menezes KK, Faria CD, Scianni AA, Avelino PR, Faria Fortini I, Teixeira Salmela LF. Previous lower limb dominance does not affect measures of impairment and activity after stroke. Eur J Phys Rehabil Med. 2017;53(1):24-31.

29. Fritz S, Lusardi M. White paper: "walking speed: the sixth vital sign". J Geriatr Phys Ther. 2009;32(2):2-5.

30. Salbach NM, O'Brien KK, Brooks D, Irvin E, Martino R, Takhar P, et al. Reference values for standardized tests of walking speed and distance: a systematic review. Gait Posture. 2015;41(2):341-60.
31. Cho KH, Lee WH. Virtual walking training program using a realworld video recording for patients with chronic stroke: a pilot study. Am J Phys Med Rehabil. 2013;92(5):371-80.

32. Lindenau JD, Guimarães LSP. Calculando o tamanho de efeito no SPSS. Rev HCPA. 2012;32(3):363-81.

33. Langhorne P, Bernhardt J, Kwakkel G. Stroke rehabilitation. Lancet. 2011;377(9778):1693-702.

34. Noveletto F, Soares AV, Mello BA, Sevegnani CN, Eichinger FLF, Hounsell MDS; et al. Biomedical serious game system for balance rehabilitation of hemiparetic stroke patients. IEEE Trans Neural Syst Rehabil Eng. 2018;26(11):2179-88.

Received in 06/03/2019

Recebido em 03/06/2019

Recibido en 03/06/2019

Approved in 10/21/2019

Aprovado em 21/10/2019

Aprobado en 21/10/2019 